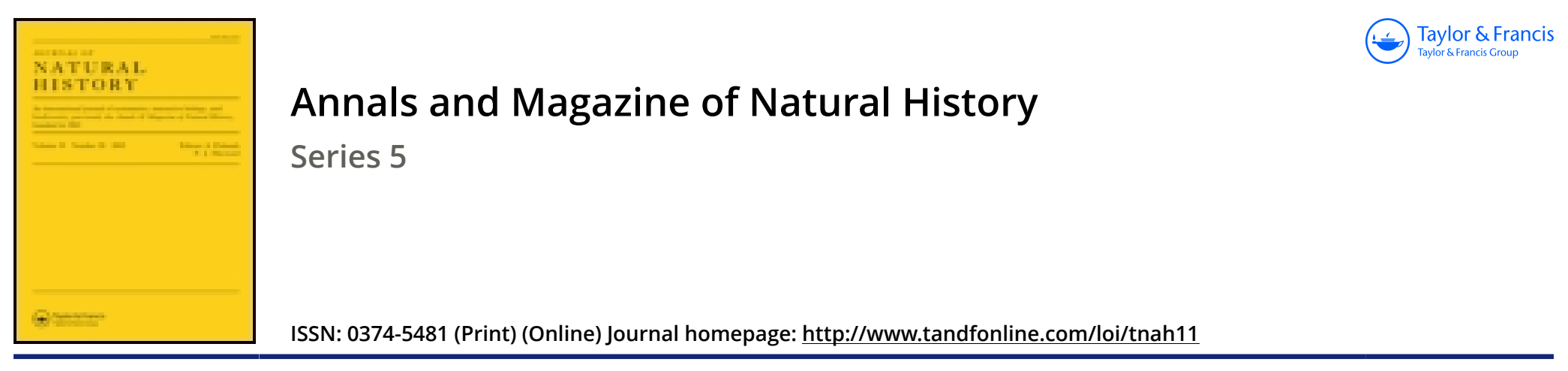

\title{
Freshwater sponges from Newfoundland: a new species
}

\section{Edward Potts}

To cite this article: Edward Potts (1886) Freshwater sponges from Newfoundland: a new species , Annals and Magazine of Natural History, 18:105, 243-246, DOI: 10.1080/00222938609459964

To link to this article: http://dx.doi.org/10.1080/00222938609459964

曲 Published online: 09 Oct 2009.

Submit your article to this journal $\sqsubset \pi$

ЏII Article views: 4

Q View related articles $₫$ 
Channel; and, in this respect, the fauna of Jersey presents a great analogy with that of Roscoff, investigated by Giard. I will cite, in the first place, Aplidium zostericola, Giard, very common on the Zosterce; and the Amaroucia, some species of which (A. Nordmanni, A. proliferum, and A. albicans, Edw.) are very abundant. The $A$ maroucia are frequently associated with Fragarium elegans and Morchellium argus, described by Giard.

Didemnum is represented by a very common species forming small corms of variable colour, generally tending to bright yellow or grey, which may be referred to $D$. sargassicola, Giard. The genus Leptoclinum is very generally distributed; it includes, in the first place, L. maculosum, Edw., forming very extensive violet-coloured corms which are found at the base of the stems of Laminarice. Associated with this, and exceedingly common, is $L$. asperum, Edw.; L. durum, Edw., and $L$. fulgidum, Edw., form greatly developed sheets, which cover the rocks; $L$. gelatinosum, Edw., lives in similar situations.

$\Lambda$ new Diplosoma is abundant at Jersey; I have found it especially upon the Laminarioe. M. Lahille, who had also observed it at Roscoff, has described it under the name of D. Kochleri.

The Botryllidæ are represented by Botrylloides rotifera and B. rubrum, Edw., and by numerous Botrylli. Besides some types, which by their coloration cannot be referred to any species described by Giard, I have met with : $B$. Schlosseri, Sav., generally the variety adonis, Giard, B. pruinosus, Giard, B. smaragdus, Edw., B. violaceus, Edw. (numerous varieties), $B$. aurolineatus, Giard, $B$. morio, Giard, and $B$. rubigo, Giard; the last two species are not so frequent as the others.

[To be continued.]

\section{MISCELLANEOUS.}

Freshwater Sponges from Newfoundland: a new Specics. by Edward Potrs.

THE author stated that in the latter part of August 1885, Mr. A. H. MacKay, of Pictou, Nova Scotia, whose success as a collector of freshwater sponges in bis own neighbourhood has been already recorded (Proc. Acad. Nat. Sci. Philad. 1884, p. 215, \&c.), made a scientific visit to the island of Newfoundland. His explorations 
were mainly limited to the irregular peninsular of Aralon, the south-easterly extremity of the island, and the record of his collections beside mentioning the neighbourhood of the city of St. Johns, embraces such familiar names as Trinity Bay, Harbour Grace, and Heart's Content, the landing-place of the Atlantic cable.

He writes, "I was extremely sorry that, owing to my limited time and the impenetrability of the interior to any ordinary effort, I conld not gain access to the great lakes in the heart and the western portion of the island. I have merely made a dip into a few of the ponds on the N. (?) E. coast." These are more particularly mentioned as Virginia and Ouidi Vidi Lakes, ncar St. Johns; Lady Lake, Bannerman Lake, Rocky Lake, and Carbonear Lake, small bodies of water near Harbour Grace; and other lakelets and brooks upon the rocky ridges and near the sea-level between Harbour Grace and Heart's Content. All this region is described as "the Canadian Huronian, the equivalent of the English Cambrian;" and the collections were generally limited to the shallow margins of the ponds, where the sponges were found upon the undersides of splinters of hard slaty quartzites, in numbers very plentiful, but generally small- " from mere points to an inch or more in diameter."

It is to be regretted that the date of Mr. MacKay's visit was necessarily so early in the year, as the specimens collected were either immature or contained only the degenerate statoblasts of the preceding season. The information gathered as to the range of temperature upon this island is valuable as indicating so far the conditions of the growth of these and other organisms.

He says: "The island is not extreme in its temperature, and the frost does not go very deep into the soil. The lakes freeze in November or December with ice at least a foot in thickness, and remain closed until the end of April. The average temperature during eight years, from 1857 to 1864 , was $41^{\circ} \cdot 2$ Fahr. Average maximum thermometer during the same time $83^{\circ}$, minimum $7^{\circ}$. In the year 1879 , the mean temperature was $40^{\circ} .2 \mathrm{Fahr}$; highest record August 3, $82^{\circ}$, lowest December $22,+4^{\circ}$. In Nova Scotia, though that is so much further south, the range is far greater, from $+96^{\circ}$ to $-20^{\circ}$ or $-24^{\circ} \mathrm{Fahr}$, with an annual average of $44^{\circ}$."

The specimens of sponges so kindly forwarded by Mr. MacKay for examination and report were more or less minute incrustations upon small stones, gathered as above indicated, and belonging to the species Spongilla lacustris, auct.; S. fragitis, Leidy ; S. Mackayi, Carter; Meyenia fluviatilis, auct.; and Heteromeyenia pictovensis and Tubella pennsylvanica, Potts. Of these Spongilla fragilis was by far the most abundant, and our knowledge of its range is thus extended along the eastern coast of North America from Florida to Newfoundland; whereas it had preriously been traced westwardly to British Columbia near the Pacifie Ocean, and more recently has been discovered in Russia, Bohemia, and England. Beside the familiar species, S. lacustris, S. fragilis, and $M$. fluviatilis, Tubella pennsylvanica has been rapidly enlarging its borders beyond the narrow limits of its original territorial designa- 
tion; while $S$. Mackayi and $H$. pictovensis had previously been known only from the discoveries of Mr. MacKay in Nova Scotia.

One other form remains to be described, and at the suggestion of its discoverer it is hereby designated

\section{Spongilla nova terra, n. sp.}

Sponge incrusting; sareodo of the young growth a dense mass of minute spherical cells, imbedding slender curving lines of fasciculated skeleton-spicules, developing later into a very loose, open tissue, with few connecting spicules.

Gemmules rather numerous, unusually large, spherical; chitinous coat thin ; "crust" apparently wanting.

Skeleton-spicules relatively few, slender, cylindrical, smooth or sparsely microspined; gradually pointed.

Dermal or flesh-spicules very abundant, minute birotulates of unequal size; shafts slender, cylindrical, occasionally spived; outer surface of rotules dome-shaped; rays prolonged, terminations acute; malformations frequent. Mixed with occasional linear, spined spicules.

Spiculos upon the gemmulæ abundant, crossing each other upon

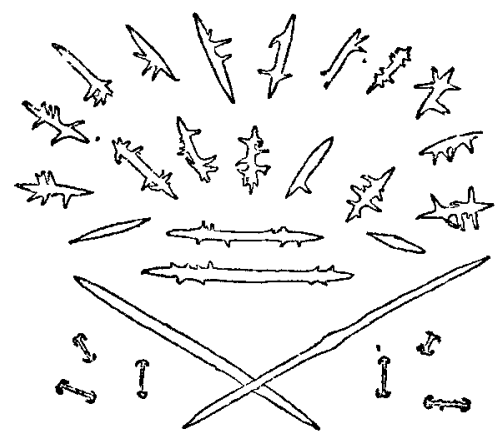
the crustless, chitinous body. Their shape when smooth is robust-fusiform, with pointed terminations; the great majority, however, have from one to six or more long spines non-symmetrically placed, but with an evident tendency to group themselves at points about one fourth the length of the spicule from one or both of its extremities.

Measurements : Diameter of gemmules 0.036 inch, skeleton-spicules $0 \cdot 0068$ by

0.0002 inch; length of average dermal spicule 0.00066 inch, of gemmula spicule $0 \cdot 00145$ inch.

Habitat. Incrusting stones in shallow water.

Locality. Lakes or ponds in the vicinity of Heart's Content, Newfoundland, collected by Mr. A. H. MacKay.

All the specimens of this sponge came from the noighbourhood of Heart's Content, but whether they were gathered from a lake upon the heights or from a brook mentioned by Mr. MacKay near the sea-level does not seem entirely clear. The accompanying illustration (magnified 225 diameters) will suggest the peculiarities of its skeleton, dermal and gemmular spiculation. The striking resemblance of the dermal spicules to the minute birotulates, heretofore only known in a corresponding position in the case of Meyznia Everetti, will at once impress the student. These are, however, 
more variable in size, are occasionally spined, and have their rays more prolonged and more delicately terminated.

It is in the singular character of the spicules surrounding the gemmulæ that this sponge must attract peculiar attention. By the system of $\mathbf{H}$. J. Carter, Esq., the freshwater sponges are now classified into six genera, besides some conditional designations of forms in which the typical features are as yet undiscovered. These six, Spongilla, Meyenia, Heteromeyenia, Tubella, Parmula, and Carterius, may again be associated into two groups, one of them including only the genus Spongilla, characterized by the linear acerate spicules surrounding the gemmulæ; and the other comprising all the other generd, where the spicule of corresponding significance is a birotulate or some easily recognized derivative of that type. Within this latter and larger group intermediate forms, connecting the defined genera, are frequent, and the location of species upon one side or other of the distinctive line comparatively unimportant. Heretofore, between the genus Spongilla and those genera composing the other group there has been "a great gulf fixed." One case only in the past has suggested their possible association, or the development of one group from the other.

In Meyenia acuminata, Potts (Proc. Acad. Nat. Sci. Philad. 1882, p. 69), since regarded as a variety of $M$. fuviatilis, the shafts of the birotulates are prolonged at each extremity, forming acuminate terminations some distance beyond the surface of the rotules. In position also these spicules are abnormal, lying flat upon the chitinous coat, instead of resting upon one rotule, their shafts taking the position of radii, as is usual in this form. In fact, we have the spicules of a Meyenia occupying the ordinary positions, and in degree approximating the forms of those peculiar to the Spongillæ.

In the present instance their intermediate character is still more striking, and while their form and position probably more closely associate them with the genus Spongilla in which the species has now been placed, the grouping of the ray-like spicules clearly suggests Meyenia. It bas been an altogether unprecedented experience with the author to hesitate between these two genera, and it will be no cause of surprise if the future teacher shall shift it from its present position.

It must not escape notice that in both of these instances the gemmulæ are without "crust;" that it is difficult to understand how birotulates could be supported in their ordinary positions without these imbedding granules; and that we may not unreasonably infer that the change in position has induced the modification of type that we here find.

This collection of sponges, including the new species, has been examined coincidently by H. J. Carter, Esq., F.R.S., and their identification and this description are believed to meet his approval. -Proc. Acad. Nat. Sci. Philad, April 6, 1886, p. 227. 